\title{
OPEN Author Correction: Hotspots of recent hybridization between pigs and wild boars in Europe
}

\section{Laura lacolina $\mathbb{D}^{1}$, Cino Pertoldi, Marcel Amills, Szilvia Kusza, Hendrik-Jan Megens, Valentin Adrian Bâlteanu, Jana Bakan, Vlatka Cubric-Curik, Ragne Oja, Urmas Saarma, Massimo Scandura, Nikica Šprem \& Astrid Vik Stronen}

Correction to: Scientific Reports https://doi.org/10.1038/s41598-018-35865-8, published online 26 November 2018

The original version of this Article contained a typographical error in the spelling of the author Vlatka Cubric-Curik, which was incorrectly given as Vlatka Cubric-Curic. This has now been corrected in the PDF and HTML versions of the Article, and in the accompanying Supplementary Information file.

\begin{abstract}
(c) (i)
Open Access This article is licensed under a Creative Commons Attribution 4.0 International License, which permits use, sharing, adaptation, distribution and reproduction in any medium or format, as long as you give appropriate credit to the original author(s) and the source, provide a link to the Creative Commons license, and indicate if changes were made. The images or other third party material in this article are included in the article's Creative Commons license, unless indicated otherwise in a credit line to the material. If material is not included in the article's Creative Commons license and your intended use is not permitted by statutory regulation or exceeds the permitted use, you will need to obtain permission directly from the copyright holder. To view a copy of this license, visit http://creativecommons.org/licenses/by/4.0/.
\end{abstract}

(C) The Author(s) 2019 